\title{
Attitudes of Knowledge and Common Sense
}

Remarks on Reid and Dewey

\section{Claude Gautier}

\section{(2) OpenEdition \\ Journals}

Electronic version

URL: http://journals.openedition.org/ejpap/1040

DOI: $10.4000 /$ ejpap. 1040

ISSN: 2036-4091

Publisher

Associazione Pragma

\section{Electronic reference}

Claude Gautier, «Attitudes of Knowledge and Common Sense », European Journal of Pragmatism and American Philosophy [Online], IX-2 | 2017, Online since 22 January 2018, connection on 01 May 2019. URL : http://journals.openedition.org/ejpap/1040 ; DOI : 10.4000/ejpap.1040

This text was automatically generated on 1 May 2019.

\section{(c) $($ ) $\odot$ (8)}

Author retains copyright and grants the European Journal of Pragmatism and American Philosophy right of first publication with the work simultaneously licensed under a Creative Commons AttributionNonCommercial-NoDerivatives 4.0 International License. 


\title{
Attitudes of Knowledge and Common Sense
}

\author{
Remarks on Reid and Dewey
}

Claude Gautier

1 In the works of John Dewey, common sense appeared as a cross-disciplinary theme, often implicated in considerations of epistemology, ${ }^{1} \operatorname{logic},{ }^{2}$ ethics ${ }^{3}$ and politics. ${ }^{4}$ There are however a number of texts where the question is addressed more directly. Amongst these can be mentioned: one of the introductory chapters of Logic: The Theory of Inquiry (1938): ${ }^{5}$ "Common Sense and Scientific Inquiry" (LW 12: 66-s.); an article published in The Journal of Philosophy in 1948 titled "Common Sense and Science: Their Respective Frames of References"; 6 and an essay in the collection Knowing and the Known (1949) 7 co-published with A. Bentley, which appeared under the title of "Common Sense and Science," which took up again the 1948a article.

2 However, the limited corpus that is directly implicated should not be misleading. It is one occasion amongst others to deploy the consequences of the pragmatist "attitude." Amongst those, reaffirming the necessity of understanding that the analysis of common sense does not spring from the specialised field of 'the epistemological industry, ${ }^{1}$ but de jure, from ethics and politics. This is the reason for which envisaging common sense per se would be an error (LW 16: 242-3).

3 Thus, while the theory of knowledge is useful to this analysis, it is only on condition that it is admitted that the knowledge implied in and by common sense is determined by its instrumental character ${ }^{10}$ and that, by way of consequence, studying its domain imposes relating it to that which it distinguishes itself from - knowledge specific to science or philosophy for example - but also, understanding the type of reality to which it refers and which it contributes to the fashioning of. This explicitly suggests the title of the 1948 article: "Common Sense and Science: Their Respective Frames of Reference."

4 Finally, the instrumental character of said knowledge allows us to envisage the effects it produces - whether in the case of common sense or in science - on the transformation of current and future conditions of experience and action, that is to say on the improvement of the material and cultural conditions of human existence. 
The relations between xixth century American philosophy and Scottish Common Sense need no further proving; ${ }^{11}$ no more than the juncture between this and the first pragmatism. ${ }^{12}$ The following study retains John Dewey, and to more exactly identify the connection between pragmatism and the philosophy of common sense, will propose elements of comparison with the philosophy of Thomas Reid (1710-96).

Several reasons justify this choice. Dewey explicitly cites Reid and Stewart in regard to one of the two definitions of common sense that he comments on taken from the Oxford Dictionary (LW 12: 68), and he takes up, in his own manner, one of the Reidian acceptances of this concept. But, beyond this very marginal reference, there is a deeper reason that supports this possible comparison.

7 One of the objectives of the philosophy of Thomas Reid is to fight against scepticism as a philosophical "attitude," radically embodied in Hume. This criticism thus implies the plan of an ethos and it does so in a specific manner: by confronting sceptical behaviour with ordinary behaviours which are related to common sense, it being understood that this confrontation bears on the status of reality from which the experience of knowledge - the "powers of intelligence" and human actions - "active powers" find their validity and their operativity.

8 As if the question of academic knowledge, natural philosophy and moral philosophy supposed, so as to be recognised in its pretensions, the proof of common sense. ${ }^{13}$ The interest of this confrontation is thus to show the importance of the relation that must be rebuilt between common sense and attitude of knowledge - in this occurrence, that of non-sceptical philosophy. Not just to affirm that a link should exist between the two types of knowledge, but also because the relation has a function which could, although this is not in Reid's vocabulary, be an aspect of a certain type of "control."

9 This confrontation of attitudes thus constitutes the method and principle of a general criticism of a certain ethos of knowledge which means to radicalise the separation of knowledge of "common sense," and knowledge of "science."

10 One of the aspects of the analysis proposed by John Dewey equally articulates attitude of knowledge, relevant to common sense, with criticism of "intellectualism," which, through fallacies of the rationalist type ${ }^{14}$ detaches itself from experience, and makes returns to experience a problem which it cannot manage to resolve. The taking into account of common sense, of the world of ordinary experiences, is for Dewey, as it is for Reid, the occasion to disqualify this type of attitude of knowledge. Of course, it remains that, beyond this convergence, the arguments and the context of problematisation should not mask the differences.

11 The discussion of common sense, in Dewey, does not only involve placing a relation between two types of attitude, it also implies, and in a more systematic fashion, the posing of the question of the relation between the development of common sense and the development of sciences. Often understood in terms of a divergence - which can express itself as a dualist opposition between common knowledge and scientific knowledge, theoretical and practical knowledge, academic and ordinary knowledge, etc. - the question of relation needs to be re-examined, according to Dewey, to identify two problems: on the one hand, to understand the manner and the reasons for which, while maintaining empirically manifest relations, the domains of common sense and science appear to oppose each other to this point, at the least being more and more independent: and on the other hand, to found the political and ethical imperative of the reconstruction 
of a deliberate and controlled "return"15 from the domain of science back to the domain of common sense.

The question of divergence also has a dimension which is not just epistemological in the usual sense, but moral: indicating the possible pathways of control of the dynamics of the domain of science when it is a case of considering the material, social and cultural consequences that it certainly produces in the common world of life.

The domain of the sciences finds in the conditions of experience relevant to the domain of common sense a source of nourishment for part of its development. In return, the progress which stems from this is not without consequences that are often imposed on and not controlled by those affected by them. This is reason for which it is necessary to become fully aware of these relationships, and even more so, to work towards directing them so as to better control the effects.

This last type of questioning, of course, is not found in an explicit manner in Reid. It supposes, historically, the intensification of the effects produced by the dynamics of technical progress and sciences, which became more and more visible in the United States from the start of the second part of the xixth century.

15 I will distinguish two moments in this presentation. In one part, I will return to the manner in which the critical qualification of an attitude of knowledge permits the posing in specific terms of the "domain"16 of common sense. In the case of Reid, it is in regard to criticism of modern scepticism in general and of Hume in particular, that this way of proceeding intervenes. In the case of Dewey, it is in regard to the criticism of intellectualism.

16 In both cases, relating to common sense allows the identification of a break, the radicalisation of which contains an aporia: the impossibility of admitting truly the existence of a knowledge of the world that is practical, and in a certain sense, realist. It is thus by the placing in relationship of a type of experience which furnishes ordinary life, and a description of experience, here most often brought to the terms of an exclusive experience of knowledge, that the implication of common sense finds part of its critical function.

17 In other terms, the reference to common sense allows us to bring out one first determinant distinction through which it becomes possible to reformulate the more general problem of knowledge: "knowledge for action" ${ }^{17}$ on one side, and on the other, "knowledge for knowledge." While this distinction is very clear in Dewey, it will be shown that it is no less easily identifiable in Reid, even if it is not thematised as such.

In another part, and this will be the second moment in this presentation, I will consider in a more specific manner the problem of relations between common sense and science, not so as to treat them in general and exhaustively, but to emphasise that that which is interesting in the point of view of Dewey resides in the placing in relation to each other of the epistemological, ethical and political dimensions of the problem. This means proposing a different reading of the divergence and effective autonomisation of progress in techniques and sciences.

19 The position of the problem in Dewey aims at the explicitation of the nature and the extent of the consequences that are certainly produced by the autonomisation of progress in sciences and the privatisation of the interests which govern it. This way of making the "return-wave" a problem that is equally moral and political, thus allows the situation of a place for possible social control of the progress of sciences. 

of progress in sciences and techniques, and making possible the socialisation of the interests to which this progress can respond, in such a way that in distinguishing the dynamics proper to common sense and to science they can remain connected. The moral and political demand for a certain control bearing on these linked dynamics should therefore set itself the task of seeing that these relationships are no longer univocal and unilaterally determined, but that they become true interactions.

From then on, with such a control, progress of techniques and sciences would no longer impose itself as a unilateral constraint of adaptation, making the human race a species which is ontologically retarded.

\section{Sceptical and Intellectualist Attitudes and the Common Sense Test}

If it is admitted that what supports the possible comparison between Reid and Dewey bears principally upon the disqualification of an attitude of knowledge and on the manner of mobilising the aid of common sense as a principle of analysis, one can start from the statement of the problem in the first to attempt, afterwards, to understand how it is translated and transformed in the second.

It is important, however, to specify that this study absolutely does not pretend to an exhaustive analysis of the positions of Reid in regard to common sense as well as all their theoretical and practical implications..$^{18}$ Methodological usage of the comparison allows me to limit what I borrow to that which emphasises the importance of the connection between the philosophy of common sense and the pragmatist reading of common sense, which surely verifies once again that which James could affirm regarding relationships between modern British empiricism and pragmatist philosophy, the reactivation of "the older English lines." ${ }^{19}$

\section{Common Sense Against Scepticism}

The practical orientation which underlies a large number of remarks bearing on the disqualification of the sceptical attitude consists, amongst other things, of valorising, in Reid, the common identity of the man of common sense and the philosopher. Some propositions taken from An Inquiry Into The Human Mind of The Principles of Common Sense $(1764)^{20}$ easily allow us to be convinced of this:

By our constitution, we have a strong propensity to trace particular facts and observations to general rules, and to apply such general rules to account for other effects, or to direct us un the production of them. This procedure of the understanding is familiar to every human creature in the common affaires of life, and it is the only one by which any real discovery in philosophy can be made. ${ }^{21}$

From Inquiry onwards, the question of attitude of knowledge is posed in terms of "constitutions," "propensities," that is to say of tendencies, the origin of which comes from a constitution. The ordinary pathway of a given type of knowledge proceeds from the particular to the general, it is inductive. And this inductive character is not first determined by an overlying reason, but is made by an acquisition supported by experiences, these being the same as those which, in ordinary life, confront us always with particular cases from which operate a certain need for generalisation. 

situations of action or of experience. "philosophy."22 the mind, mistakes his aim. ${ }^{23}$ sense and our education are there to resist this: odds but we end in absolute scepticism. ${ }^{25}$

Induction before being logically characterised - as opposed to deduction or syllogism - is the expression of a form of the "relation" of exchange which the ordinary man in the common affairs of life - "reasoning on common life" - knits with his environment of action and experience. It is the form of an attitude which permits practical inferences which, like those of the craftsman, confront particular cases to render them operative in other

However, Reid says something else: that inference as a propensity is borne by the search for effects, for consequences ("to show us how to produce them (effects)"). To put it in another way, the demand for generalisation, here, is not given for itself, but is implied by the sequence which aims at identification of certain effects, of their "production."

The consequence of this is clearly formulated: it is this attitude which must serve as the departure point for the practice of all types of knowledge ("it is the only one by which any real discovery in philosophy can be made"). It is therefore the same attitude which must prevail for the two types of knowledge, that which aims at the improvement of affairs in life, and that which aims at the elaboration of a distinct knowledge, that which is called

The man who first discovered that cold freezes water, and that heat turns it into vapour, proceeded on the same general principles, and in the same method, by which Newton discovered the law of gravitation and the properties of light. His Regulee philosophandi are maxims of common sense, and are practised every day in common life; and he who philosophizes by other rules, either concerning the material system, or

Thus, continuity between the two attitudes is claimed even more explicitly, Reid affirming that the method which allowed Newton to discover the universal laws of gravity is drawn from the "maxims of common sense," those which are daily "practised."

The general form of inference is thus common and it is this that characterises all the attitudes of knowledge, whether they bear on affairs of life or upon more complex questions - "the material system or the mind." It is indeed the identity of nature of complexities implied in the activity of knowledge which supports this commonality.

So there is no reason here to make a difference between "the craftsman in his shop" and the "philosopher," Hume restates. ${ }^{24}$ Both of them find in this that it is possible to improve the precision of that which is known in ignorance of first causes, final causes, or "first principles." On that level, nothing distinguishes the two attitudes ontologically.

It is unfounded will to install a rupture which characterises sceptical philosophy. Common

And if common sense or the principles of education happen not to be stubborn, it is

"Our" common sense, the consolidation of which is permitted by education, gives the means to avoid giving up to an "absolute scepticism." Common sense is thus not just the specific domain of practical life and of a type of knowledge - that of ordinary experiences - it is equally acting under the form of an array of incorporated dispositions, which, by their consolidation ("the results of our upbringing"), resist the corrosive power of this other inclination "doubting." This spontaneous, and then controlled resistance is therefore that which allows rupture to be avoided with all of its vertiginous consequences.

4 Common sense, as an "environment" and as an "array of propensities" is thus links in a vital manner to human attitudes, since defective relationships with its domain condemns 
those concerned to madness. Once again, here is what Reid says with regard to the hyperbolic doubt of Descartes:

A man that disbelieves his own existence, is surely as unfit to be reasoned with, as a man that believes he is made of glass. There may be disorders in the human frame

that may produce such extravagancies, but they will never be cured by reasoning. ${ }^{26}$

\section{"constitution}

Descartes, Malebranche and Locke, have all employed their genius and skill to prove the existence of a material world; and with very bad success. Poor untaught mortals believe undoubtedly, that there is a sun, moon and stars; an earth, which we inhabit; country, friends, and relations, which we enjoy; land, houses, and moveables, which we possess. But philosophers, pitying the credulity of the vulgar, resolve to have no faith but what is founded upon reason. ${ }^{28}$

The sceptical attitude and the attitude guided by common sense separate from each other here on the manner of consolidating, by experience, action and belief where, precisely, the sceptic interrupts this sequence to limit it to the sole moment of belief which corrosive reason questions and places in doubt:

It is a bold philosophy that rejects, without ceremony, principles which irresistibly govern the belief and the conduct of all mankind in the common concerns of life; and to which the philosopher himself must yield, after he imagines he hath confuted them. Such principles are older, and of more authority, than Philosophy: she rests upon them as her basis, not they upon her. ${ }^{29}$

The sceptical attitude disassociates knowledge from action; it separates the immediate end and immediately practical, which makes the knowledge, or this type of knowledge, a means of action, a means without which action is quite simply unrealisable. However, man doted with common sense believes in the existence of the earth because he lives there; he believes in his friends because they are a source of joys and pleasures; in the same manner, he possesses the house and furniture in which he lives and for which there is no practical reason to doubt in their existence, etc.

It is thus the ordinary relation - daily reiterated, confirmed and consolidated - of given forms of action and experience which allow the indubitable character of the world to be placed. The exteriority and reality of the world without which action is quite simply impossible. From there, and from the point of view of common sense, experience and action are conducts which support each other to accomplish their movements and arrive at their ends, at a reality from which they proceed and of which there is no reason to doubt. The age and authority of these principles - "the belief and the conduct of all mankind in the common affairs of life" - are the foundation of all practical knowledge, and, as the last citation suggests, should equally be so for philosophy.

European Journal of Pragmatism and American Philosophy, IX-2 | 2017 

insuperable breach between the two domains - that of practical knowledge and that of philosophy understood here as science -; the major consequence is the impossible affirmation, from the point of view of reason, of the reality of the exterior world and the human mind:

[...] and as the Bishop (Berkeley) undid the whole material world, this author (Hume) upon the same grounds, undoes the world of spirits, and leaves nothing in nature but ideas and impressions, without any subject on which they may be impressed. ${ }^{30}$

41 The conclusion of this reasoning is this: if one adopts the attitude of sceptical philosophy, of which Hume would be the most complete expression according to Reid, two worlds find themselves resolutely separated, no longer allowing common sense to take hold. On one side, there would be men acting, motivated and directed by unfounded beliefs in a common and ordinary, but illusory, world. On the other side, there would be philosophers who strive to found in reason what could be the reality of an exterior world and which is forever out of their reach.

What Reid's thesis shows, is that there really is, on one hand, a world of common sense where the experiences of perception and human actions daily come to confirm its external reality and consistence, and on the other hand, a world of sceptical philosophy, of which the illegitimately extended usage of reason leads to making the external world into something elusive and inaccessible, and thus reducing common experiences and beliefs into nothing but vain fancies. ${ }^{31}$

In that, the sceptical attitude is really that which destroys the world, the mind, and the identity of the subject. In that, equally, to return to common sense, to restore the legitimacy and the legality of its domain, is to prove the sophist character of an attitude of knowledge which, in the name of excessive pretensions bearing on the powers of reason, separates that which is "irresistibly" linked: to act and to believe by the intermediary of the senses, in the reality of the exterior world.

In that, therefore, the philosophy of common sense such as it is here claimed by Reid, is really the condition of the possible reconstruction of a certain realism: that of the world of ordinary life, that of vital relationships between knowledge and practices, that of sequences that are reiterated between experiences of knowledge as resources "in view of" human action and conservation.

The rehabilitation of common sense appears in Reid as the occasion to reveal the idealist character of the sceptical posture which renders the world unreal - by the criticism of matter in Berkeley - and casts into doubt as far as the very existence of a subject of perception - by the reduction of the real in the world of impressions and ideas in Hume.

Scepticism is thus to Reid an idealism, since it manages to destroy even the evidence of the reality of the exterior world without which there is no conservation of a "self." It poses as problematic the general form of a stable relationship between the world of common sense and the world of critical or philosophical knowledge, which comes back to saying that the sceptical attitude renders the two worlds incommensurable, that of practice and common sense, and that of academic knowledge and science.

47 If the question of the specific interpretation of the sceptical theses of Hume is put to one side it will be accorded, therefore, that the problematic of common sense such as it is formulated in Reid, at least in that which we have retained here, allows a triple result: (1) 
revealing the fallacious character of the question of realism where it raises a certain philosophical attitude; (2) giving back a hold to practice and action for which a certain type of knowledge is indispensable and legitimate; (3) restoring the unity, that is to say the effectiveness of the relationship between the domain of common sense and the domain of science which the paradigmatic example remains, in the eyes of this Scot, that of Newton.

I wish to show that some of the considerations of John Dewey on common sense can be situated in a comparable manner. Put another way, taking account of the fashion in which the statement of this question finds part of its pertinence in the criticism of a philosophical attitude which is that of "intellectualism," and which is supported by the reconsideration of the nature of experience and its relation to knowledge.

\section{Common Sense Against Intellectualism}

In the first chapter of Experience and Nature, ${ }^{32}$ Dewey attaches himself to the distinction of what he terms "philosophical method" from "empirical method." What is at stake in this comparison is the aptitude of these methods to take account of experience, all experience and all experiences.

By "intellectualism" as an indictment is meant the theory that all experiencing is a mode of knowing, and that all subject-matter, all nature, is, in principle, to be reduced and transformed till it is defined in terms identical with the characteristics presented by refined objects of science as such. The assumption of "intellectualism" goes contrary to the facts of what is primarily experienced. For things are objects to be treated, used, acted upon and with, enjoyed and endured, even more than things to be known. They are things had before they are things cognized..$^{33}$

The accusation of intellectualism thus designates a precise theoretical gesture: the fact of having an experience finds itself assigned to the exclusive function of knowledge and "things," which, in the ordinary course of experience, are also "means" or "instruments" for action, implied in the sensations, affections and wishes, which find themselves, by an effect of posture, reduced to the status of an "object" of knowledge. This reduction operates on two levels: it transforms the "thing" into an object for knowledge; it brings back the content of the experience to the status of an exclusive instrument of knowledge. ${ }^{34}$ Which therefore implies that:

When intellectual experience and its material are taken to be primary, the cord that binds experience and nature is cut. ${ }^{35}$

51 Experience so understood thus introduces a breach with nature. It renders the activity of knowledge foreign to nature and makes nature into an exteriority which always escapes experience, with which it has no relations. The relation "act - be affected by," which is the first form of the relation of exchange between nature and an organism, certainly contains a dimension which is originally cognitive, but this is not however always already an effective knowledge. ${ }^{36}$ The problem, for the "empirical philosopher" will be to understand how it can become one in the movement itself of experience. So as not to break the continuum "nature/experience" and to avoid supernatural explanations, good philosophical method must therefore admit that cognition is only one dimension amongst others of the fact of experiencing.

However the breach "nature" - "experience," which is the fact of the intellectualist posture, brings with it other consequences which return to the question of common 
sense. We are thus exposed to disregarding other dimensions of reality of the world which we experience:

When real objects are identified, point for point, with knowledge-objects, all affectional and volitional objects are inevitably excluded from the "real" world, and are compelled to find refuge in the privacy of an experiencing subject or mind. ${ }^{37}$ experiences do, within which are implied affectivity, will, etc.: problem and purpose in hand. ${ }^{38}$ question of knowledge is not posed as an end in itself. knowledge for itself. sense from that of science. everything that bears upon "ordinary matters." which is posed from the point of view of reason.

As James says in defining "rational fallacy": and higher nature. All the while it is their nature. ${ }^{40}$

In effect, the primacy accorded to reason leads to the ignorance of what the most ordinary

But in ordinary matters and in scientific inquiries, we always retain the sense that the material chosen is selected for a purpose; there is no idea of denying what is left out, for what is omitted is merely that which is not relevant to the particular

The posture of the intellectualist philosopher is built upon the disqualification of a whole world of experience which is also the world of common sense, at least, a world where the

Passing from the "philosophical method" to the "empirical method" in the sense already given, is not to make a difference of nature between the posture of the "philosopher" that John Dewey designates by the expression of "empirical philosophy," ${ }^{39}$ that of the "scientist" and that of the "ordinary man." That community of nature engages in the same way, the agent implied in a concrete or practical action, the scientist and/or technician leading an enquiry to experiment certain types of consequence in a situation deliberately chosen and constructed, and finally the philosopher, who pretends to identify the specificity of

In every case, the choices thus operated do not equivalate to the denial of that which is put aside from reality. This is still partially determined, that is to say valorised, by a type of sought outcome. From there, the constitution of an "empirical philosophy" cannot rest upon the radicalisation of the breach between experience and nature because such a breach envelopes, in the same gesture, all that which separates the domain of common

in Reid, the direct confrontation of the sceptical attitude with the conduct of common sense allows the display of the manner in which scepticism leads illegitimately to rendering the world unreal, the world of things and matter in Berkeley, that of conscience and identity in Hume, in Dewey the criticism of intellectualism allows the display of the manner in which this attitude drives out a whole part of reality, notably by the ontological disqualification of everything which ordinarily is made of experience, of everything that commonly supports the movement of our actions. To encapsulate,

Intellectualism is therefore an idealism that subsumes a trait or a character of real experience to make of it the paradigm of all experience. And as an idealism, it disqualifies the domain of common sense which, from that fact, remains bogged down in a world that is ontologically incomplete, unfinished and devalued, since it does not conform to that

The rationalist's fallacy here is exactly like the sentimentalist's. Both extract a quality from the muddy particulars of experience, and find it so pure when extracted that they contrast it with each and all its muddy instances as an opposite 
The critique of the intellectualist attitude allows the adoption of the "empirical method" precisely because it starts from experience, all experience, and returns to experience. It is the only method which permits the positive consideration of "common sense" as a domain of reality which is experienced. But this rehabilitation does not aim at common sense such as it is. Making it the object of the empiric method thus supposes that it be put in relationship, related to, notably through analogies, with science.

61 It is thus that it can be admitted that the scientist, to make his inquiry, makes deliberate choices, which does not at all mean that he denies the reality of that which he puts to one side. Just as the man of common sense accesses a type of practical knowledge linked to an end, itself also practical, and of which the articulation means/end leads to other choices. Is only the philosopher, or at least one that adopts the intellectual attitude, is to be dispensed from such conduct, instituting his choices in a "pure" and "absolute" reality?"

In the essay "Common Sense and Science: Their Respective Frames of References," Dewey takes the example of water to show all the multiplicity of "references" engaged in the multiplicity of experiences bearing on these "ordinary matters":

How, for example, should the water of direct and familiar acquaintance (as distinct from $\mathrm{H} 2 \mathrm{O}$ of the scientific frame) be described save as that which quenches thirst, cleanses the body and soiled articles, in which one swims, which may drown us, which supports boats, which as rain furthers growth of crops, which in contemporary community life runs machinery, including locomotives, etc.? ${ }^{42}$

To experience, to act, supposes therefore really choices through the bias of a "selective emphasis." ${ }^{43}$ That which is retained or put to the side is different because it is always directed by different interests to reply to different goals. It is in that that the three attitudes, of the ordinary man, the scientist, and the philosopher, should be compared. They are part of a common "ethology." 44

The reduction of the thing to an object of knowledge is thus acceptable, for the philosopher, as for the scientist, on the double condition of not forgetting that it is a case here of a valorisation which answers to a choice and that that choice always implies the exclusion of other "characteristics," ${ }^{45}$ other determinations of the thing and therefore other elements of the real which can be experienced. In the frame of another type of experience, and of another attitude, that which has previously been removed will be retained as "indispensable" and as equally "real," (LW 1: 31).

If it is to be found that in the course of ordinary experiences, this principle of selection, often ignored, does not lend itself to consequence because of the diversity of interests which are given to things, it is not the same for philosophy which, again emphasises Dewey, proves itself to have a regressive attachment to that particular moment of experience which is that of its dimension of knowledge, (LW 1:31).

The "empirical method" (LW 1: 34), analogically constituted on the model of experimental empiricism, thus renders explicit the consequences which result from a "choice," will reconstruct the singularity of the path which goes from this choice until the obtained result, and will test the relative value of it. ${ }^{46}$

Critical demands belonging to the empirical method which permit the validation of its exactitude, therefore redirect the movement of knowledge towards the elucidation of the course of ordinary experience:

What empirical method exacts of philosophy is two things: First, that refined methods and products be traced back to their origin in primary experience, in all its heterogeneity and fullness; so that the needs and problems out 
of which they arise and which they have to satisfy be acknowledged. Secondly, that the secondary methods and conclusions be brought back to the things of ordinary experience, in all their coarseness and crudity, for verification. ${ }^{47}$

The empirical method, in philosophy, should permit the reestablishment of the continuity between knowledge and the ordinary course of experience, or, as he says several pages late:

There is a special service which the study of philosophy may render. Empirically pursued it will not be a study of philosophy but a study, by means of philosophy, of life-experience. ${ }^{48}$

The "empirical method," in its experimentalist dimension, thus becomes again a means, an instrument, and not, as in the intellectualist attitude, a finality which expects to relive philosophically problems which are philosophical or for philosophers. It is indeed in this reversal that the passage from one to the other of philosophical attitudes resides, a passage which thus permits making of "ordinary matters" and the domain of common sense a privileged object of all philosophy.

\section{Between Common Sense and Science: The Demand for an Attitude of Control}

\section{Science is not Independent of Common Sense in Reid}

70 Analysis of the relationships and implications between science and common sense is not a specific object of Reid's critical approach; however, scattered considerations can be found there which permit the defining, by omission, of certain principles of that analysis.

If common sense could act as a critical proof with regard to the sceptical attitude, ${ }^{49}$ if the man of common sense is gifted with dispositions which permit him, spontaneously or through education, to resist doubt when he is engaged in the affairs of ordinary life - and he is permanently - disqualification of scepticism does not ipso facto bring with it the disqualification of science. Between the two domains, there exist more than one possible continuity.

In the introductory chapter to his Inquiry, Reid recalls that the inferential and inductive procedure which allowed Newton to establish the laws of gravitation is analogous to that which is employed in the reasoning of common sense..$^{50}$ Without doubt it must be added, in a formulation which this time I borrow from Dewey, that:

in fact science practiced today began only when the work was refined and extended

by adoption of material devices and technological operations. ${ }^{51}$

Sciences intervenes as an instrumental mediation which has as a possible consequence the invention and the construction of new systems of observation, which come to modify, enlarge, and extend the capacities of experimentation of that which is given in the universe of common sense, at least at first.

This modified continuity of the relationship between common sense and philosophy ${ }^{52}$ is emphasised. It is implied in a recurrent fashion in Inquiry, where notably the faculties of perception are analysed and the distinction of principle between "sensation" and "quality" is posed. An example amongst others:

It is the business of philosophers to investigate, by proper experiments and induction, what heat and cold are in bodies; [...] these questions are within the 
province of philosophy; for common sense says nothing on the one side or the other. ${ }^{53}$ judgement or idiocy (Inquiry, VI, 20, ibid.). Reid recalls this once more when he evokes the belief accorded to the information given us by nature:

And now when I reflect upon what is past, I do not find that I have been imposed upon by this belief. I find, that without it I must have perished by a thousand accidents. I find, that without it I should have been no wiser now than when I was born. ${ }^{55}$

The frontier which permits to thus mark out this epistemology of the evidence is brought by the taking into consideration of the consequences that the beliefs which support it permit to produce or to avoid. The evidence is only the statement on an epistemological level of the operative and primary character of the anthropological principal of conservation. 
81 On the other hand, the growth of the distances covered by inductive inference and the indirect character of the results associated with it allow the domain of understanding of science to be defined. It distinguishes itself from common understanding as does close from far, as does the immediate from the mediate.

These distinctions underline the complementarity that is found in the listing of diverse sciences coming from the domain of science: agriculture, medicine, etc. The growth of knowledge is thus not without effect upon the common world of experience and human conducts.

While Reid does not say so explicitly, it can nonetheless be understood, here, that the development of the arts and sciences is indeed a general factor in the improvement of the conditions of life in society. The two understandings, being distinct, are therefore no less linked together: the forms of the ordinary practice of men of common sense are influenced and modified by the enlargement of knowledge produced by the sciences.

The question thus bounded by the means of the distinction of understandings allows the recognition of all the positive side of a knowledge borne by observation and experience. ${ }^{56}$ A knowledge which, in its turn, produces fortunate effects - civilisation, notably - upon the ordinary conduct of life.

So there is no reason to think that, in Reid, the practical and continuous reference to common sense in the ordinary course of human actions and experiences as a practical mode of verification of the value of beliefs to consequences produced by the spontaneous character of the "attitude" of resistance to doubt leads towards a substantial conception of common sense and its domain.

The evocation of the relationships between common sense and science, the recognition of the progress of knowledge, largely display the dynamic character of the domains of common sense and of science. The naturalist argument that here supports a part of the Reidian epistemology of the evidence is thus not in contradiction with a certain historical reading of the contents and the limits of the world of common sense.

\section{The Necessary Control of Interactions Between Science and Common Sense in Dewey}

87 As I have since the start of this study, I will limit my subject to the question of attitudes of knowledge. It has been shown that it is not on the level of "logic"57 that the methods of knowledge coming from common sense and science can be distinguished. From this point of view, it suffices to "unify" them once more (LW 12: 84) for this is the paradigm of the inquiry which prevails both here and there.

88 This continuity, thus underlined by the logical unity of the investigatory method, is equally supported by another common property: in the domains of common sense and science, it is "human affairs."

I begin by saying that however the case stands, they are not to be distinguished from one another on the ground that science is not a human concern, affair, occupation. ${ }^{58}$

This community of nature should be enough to make it understood that in reality common sense and science are always effectively linked together. To talk of the autonomisation of the sciences is therefore an error: 
A part of the problem involved (an important part) being how it happened that the scientific revolution which began a few short centuries ago has had as one outcome a general failure to recognize science as itself an important human concern, so that, as already remarked, it is often treated as a peculiar sort of entity on its own account. $^{59}$ 
idealistic position which would have as its counterpart the disqualification of science as such..$^{65}$ It is a case of understanding that the demand for control rests principally upon just appreciation and valorisation of their distinction:

(T)hey are not to be distinguished from one another on the ground that science is not a human concern, affair, occupation. For that is what it decidedly is. The issue to be discussed is that of the kind of concern or care which marks off scientific activity from those forms of human behaviour that fall within the scope of common sense. ${ }^{66}$

If, in both cases the attitudes of "doing" and "knowing" prevail as much as each other, it remains that their articulation differs and that for science, the attitudes are deployed with the motive of advancing the "system of knowings" and the "system of knowns." Which should not lead us to forget that:

(W)hat science is of is about what common sense subject-matter is of, (and that this fact) is disguised from ready recognition when science becomes so highly developed that the immediate subject of inquiry consists of what has previously been found out.

Several factors lead thence to see as radically autonomous and separate that which stems from the dynamic of the sciences. There is the fact that the growth of specialisation nourishes by itself the demand for knowledge: it is a case of replying to the demands belonging to the results, which are always provisional, of the inquiry that is in course. If the movement is envisaged in its temporal continuity, then that which precedes implies a part of that which will succeed it.

101 The articulation of the present and the future is, at least in part, borne by the fact that the given and actual state of a type of knowledge conditions the future and potential development of the knowledge. This is what the use emphasised by Dewey here of adverbs of time such as "immediately" and "previously" suggests. This internal and external dimension of the progress of knowledge, for science, should not mask the fact that the point of departure remains that of "common sense subject-matter(s)."

102 To this first fact is added another which is determinant. There are always specific interests of knowledge, and these interests are neither general nor universal. Because knowing scientifically is a fundamentally human affair, it is erroneous and dangerous to believe that scientific growth did not develop in the perspective of primordially human affairs.

103 The problems that are chosen to be resolved, in a word, the interests of knowledge, do not emerge in a contingent manner; they are tributary to circumstances and relationships of strength. Because the problems to be resolved do not select themselves, there is really a specific direction given to the development of knowledge and the organisation of the inquiries which are linked to it. Inquiries are thus influenced in their orientation and their achievement by human factors and dominant interests. ${ }^{69}$

There are thus indeed relationships between science and human affairs, between the interests of science and the interests of the group. These are precisely the relations which are masked and it is there that resides, for Dewey, the philosophical nature of the problem of relationships between common sense and sciences:

In any case, it is harmful as well as stupid to refuse to note that scientific knowing is one human concern growing out of and returning into other more primary human concerns. [...] There is, then, a problem that is of philosophical concern in this matter of the relation of the concerns of common sense and of science with each other. ${ }^{70}$ 
From there, the difficulty is really that which consists of admitting that although science finds its origin in the matrix of activities of common sense, its return is not evident. As Kennedy reminds us in his gloss, "Science takes its departure from common sense but the return road has been blocked." 11

The autonomisation of dynamics is therefore not real, that of science is really determined by private interests and the whole philosophical and political question is to socialise the interests in the name of which such a dynamic of development of scientific knowledge can be reorientated. Here is the perfectly explicit statement of the moral and political problem which is raised by the articulation between common sense and science from the point of view of attitudes of knowledge:

The problem, then, concerns the possibility of giving direction to this return-wave so as to minimize evil consequences and to intensify and extend good consequences, and, if it is possible, to find out how such return is to be accomplished..$^{72}$

The political question is thus double: firstly, it supposes the explicitness, historically and empirically, of the particular interests which direct the problems treated and the inquiries put in place. It means avowing the always-dependent character of the progress of that knowledge, and making appear the relationship between attitudes of knowledge and the accomplishment of situated and private particular interests. Even knowledge for its own sake is a situated knowledge which envelopes the taking into account of conditions of space and time which make of its progress a specifically oriented progress.

It is a case, next, starting from a non-idealistic and non-moralising concept of the development of science, of showing that it is not the principle itself of the relationship of all knowledge with specific interests that must be condemned or brought into question. It is an enlargement or socialisation of interests that must be achieved so as to not block the "return-wave" in the direction of common sense.

Such a socialisation being finally one of the essential conditions to rediscover that which equally defines the attitude of scientific knowledge, its liberative power:

The liberative outcome of the abstraction that is supremely manifested in scientific activity is the transformation of the affairs of common sense concern which has come about through the vast return wave of the methods and conclusions of scientific concern into the uses and enjoyments (and sufferings) of everyday affairs; together with an accompanying transformation of judgment and of the emotional affections, preferences, and aversions of everyday human beings. ${ }^{73}$

The problem of common sense and the paths of its controlled transformation thus reside in the extension of the interests which support the development of knowledge in the domain of the sciences, and in the manner of generalising the interests in the name of which such a domain develops. It is only in this context that the knowledge allows its liberative power to be shared.

1 The problem is thus not only philosophical, it is political and practical. It supposes a transformation in the organisation of society which brings back into cause the private character of the interests which support the development of science.

Because the affairs of science are human affairs, because the control of the conditions in which men act and make experiments is the only path to take with the direction of improvement of the conditions of life, the completely academic question of interactions between "common sense" and "science" should be reformulated in the terms of a practical question. 
113 This question engages, on one hand, the elucidation of the respective attitudes of knowledge in terms of what they have in common and in how they are distinct, and on the other hand, reaffirms the political necessity to orientate the flux of the "return-wave" towards the shared transformation of the "world," that is to say of the "common sense environment." ${ }^{74}$

\section{To Conclude...}

114 The pragmatist analysis of common sense in Dewey that we have proposed does not pretend to synthesise all the problems that it raises. It seems to us enlightening, on one hand, to show that a certain number of the preoccupations that define the approach of Dewey, are echoed in the tradition of Anglo-Scottish modern empiricism.

115 In this sense the comparison with Reid should not be understood as a historiographical effort to reconstruct a lineage - the criticisms levelled by Dewey towards modern empiricism are sufficiently recurrent to avoid this error.

116 It aims rather, by a methodological alignment, to indicate a certain convergence of preoccupations. It is starting from the ethos of knowledge that it seems possible to understand how the test of common sense permits the relativisation of the critical pretensions of the sceptical attitude, and to avow the illegitimate pretension of the intellectualist attitude.

117 In both cases, this test was also the occasion for a requalification of reason which must be admitted to support all experiment, whether it be implicated in the practical movement of actions "in view of" or in the specific form of an activity of knowledge for itself. Common sense, realism, and attitudes of knowledge thus support an approach in terms of relationships which I think I have shown it is possible to find traces of in Reid.

118 It is thus possible to understand, starting from this, that the problem of common sense cannot be separated from that of the qualification of the relationships that it holds with science and its development. From there, the question of the attitude of knowledge must be linked together with that of the interests of knowledge. The question is not only raised from epistemology, it implies a moral and political range and makes, now, of the world of common sense, that which should be reconstructed as the complete and integral destination of the "return-wave."

119 It is just because the environment of common sense is not the destination of progress in the sciences that it finds itself transformed without the flux which transforms it being truly controlled so as to make it the occasion for a larger and shared improvement of the ordinary conditions of life and experience. 


\section{BIBLIOGRAPHY}

BENTLEy A. \& John Dewey, ([1949] 1991), “Common Sense and Science,” in John Dewey, chapter 10, LW 16, Ann Boydston (ed.), Introduction T. Z. Lavine, Nagel, Southern Illinois University Press, 242-s.

DEWEY John, ([1899] 1986), “Consciousness and Experience,” The Middle Works, 1899-1924, vol. 1, J. A. Boydston, ed., Carbondale, Southern Illinois University Press, (MW 1).

DEWEY John, (1905), “The Postulate of Immediate Empiricism," Journal of Philosophy, Psychology and Scientific Methods, 11 (15), in The Middle Works, 1899-1924, vol.3, J. A. Boydston, ed., Carbondale, Southern Illinois University Press, (MW 3), 158-67.

DEWEY John, (1910; 1933), How We Think?, The Middle Works, 1899-1924, vol.12, J. A. Boydston, ed., Carbondale, Southern Illinois University Press, MW 12; The Later Works, 1925-1953, vol. 8, J. A. Boydston, ed., Carbondale, Southern Illinois University Press, (LW 8).

DEWEY John, (1910), The Influence of Darwin on Philosophy and Other Essays, The Middle Works, 1899-1924, vol. 6, J. A. Boydston, ed., Carbondale, Southern Illinois University Press, (MW 6). DEWEY John, ([1925] 1981), Experience and Nature, The Later Works, 1925-1953, vol. 1, J. A. Boydston, ed., Carbondale, Southern Illinois University Press, (LW 1).

DEWEY John, (1927-46), The Public and its Problems, The Later Works, 1925-1953, vol. 2, J. A. Boydston, ed., Carbondale, Southern Illinois University Press, (LW 2).

DEWEY John, ([1929] 2008), The Quest for Certainty, The Later Works, 1925-1953, vol. 4, J. A. Boydston, ed., Carbondale, Southern Illinois University Press, (LW 4).

DEWEY John, ([1938] 1991), Logic: The Theory of Inquiry, The Later Works, 1925-1953, vol. 12, J. A. Boydston, ed., Carbondale, Southern Illinois University Press, ( (LW 12).

DEWEY John, ([1939] 1991), The Theory of Valuation, The Later Works, 1925-1953, vol. 13, J. A. Boydston, ed., Carbondale, Southern Illinois University Press, (LW 13).

DEWEY John, (1948a), “Common Sense and Science: Their Respective Frames of Reference,” The Journal of Philosophy, 45, 8.

DEWEY John, (1948b), Essay “The Revolt Against Science,” The Later Works, 1925-1953, vol. 15, J. A. Boydston, ed., Carbondale, Southern Illinois University Press, (LW 15).

DEWEY John, (1949), The Knowing and the Known, The Later Works, 1925-1953, vol. 16, J. A. Boydston, ed., Carbondale, Southern Illinois University Press, (LW 16).

HUME David, ([1739-40] 2007), A Treatise of Human Nature : A Critical Edition, David Fate Norton \& Mary J. Norton (eds.), Oxford, Clarendon Press ("The Clarendon Edition of Works of David Hume").

HUME David, ([1748] 1999), An Enquiry Concerning Human Understanding, Tom L. Beauchamp (ed.), Oxford, Oxford University Press ("Oxford Philosophical Texts").

HUME David, ([1779] 2007), Dialogues Concerning Natural Religion and Other Writings, Dorothy Coleman (ed.), Cambridge, New York, Cambridge University Press ("Cambridge Texts in the History of Philosophy"). 
JAMES William, (1907; 1975), "Pragmatism and Common Sense," Pragmatism, The Works of William James, Cambridge Massachusetts, Harvard University Press, Vol. 1.

KENNEDY Gail, (1954), "Science and the Transformation of Common Sense: The Basic Problem of Dewey's Philosophy," The Journal of Philosophy, 51, 11, May 27.

MILL John-Stuart, (1994 [1843]), The Logic of the Moral Sciences, Open Court Publishing Company, USA.

REID Thomas, $(1764 ; 1995 ; 2015)$, An Inquiry Into The Human Mind of The Principles of Common Sense, The Edinburgh Edition of Thomas Reid, Derek R. Brooks (ed.), Oxford, Oxford University Press.

RENAULT Emmanuel, (2015), “Dewey et la connaissance comme expérience. Sens et enjeux de la distinction entre 'cognitive,' 'cognitional' et 'cognized' ou 'known'," Philosophical Inquiries. Revue des Philosophies anglophones, Vol. 5, 19-43.

SEGREST Scott Philipp, (2009), America and the Political Philosophy of Common Sense, "The Eric Voegelin Series in Political Philosophy," Columbia and London, University of Missouri Press. SOMERVILLE James, (1987), “Reid's Conception of Common Sense,” The Monist, Oct. 1, 70-4.

\section{NOTES}

1. For example, it can be considered that the analysis proposed by How We Think? (MW 12: 77-s.; LW 8: 105-s.) in Chapter 15 "From the Concrete to the Abstract" (LW 8: 193-s.) directly implies the question of common sense: 196 especially.

2. Dewey (LW 12, I: 7-102). As well (LW 4: 8). "The Naturalization of Intelligence," 156-s., 9. "The Supremacy of Method," 178-s.

3. Dewey (LW 13, IV). "Propositions of Appraisal," 208-s.

4. See Segrest 2009.

5. Dewey (LW 12: 66-85).

6. Dewey, (1948a: 197-208).

7. Bentley \& Dewey 1949, in Dewey (1991: chapter 10, LW 16: 242-s.).

8. Dewey (MW 6, "Preface": ix-xii); Essay "The Influence of Darwinism on Philosophy": 17-8.

9. Dewey (MW 1: 122).

10. "In the concerns of common sense knowing is as necessary, as important, as in those of science. But knowing is there, for the sake of agenda the what and the how of which have to be studied and to be learned - in short, known in order that the necessary affairs of every day life be carried on." (LW 16, my emphasizes).

11. Scot Ph. Segrest 2009, already cited, thus shows the important role which figures such as John Witherspoon (1723-94) and James McCosh (1811-94) played in the importation and appropriation of Scottish Common Sense in America. (Segrest 2009: 3. "Witherspoon's 'Plain Common Sense'," 64s.; 4. "McCosh's Scientific Intuitionism," 101-s.) Starting from an analysis of the corpus of William James, he gives an account of the connection between this tradition of common sense and the first pragmatism (Segrest 2009: 3-s. and 5. "The Common Sense Basis of James's Pragmatic Radical Empiricism," 133-s.).

12. See, for example, James 1907: "Pragmatism and Common Sense" in Pragmatism: A New Name for Some Old Ways of Thinking, in 1975: Pragmatism, The Works of William James.

13. For a first approach to the different significances of the occurrences of "common sense" in Thomas Reid, see Somerville (1987: 418-29).

14. So as to take up the typology proposed by James (1907), Pragmatism, Lecture VI "Pragmatism's Conception of Truth," in The Works of William James, 1: 109-s. 
15. The expression employed by Dewey, notably in (1948: 207-s.; LW 16: 255), with regard to this "return" of consequence - from the domain of science towards that of common sense - is that of the "return-wave."

16. The designation of this "domain" leads to real terminological proliferation in the articles of Dewey. So, just to take the example of "Common Sense and Science: Their Respective Frames of References" (LW 16: 242-57), Dewey talks of "traits of Common Sense," of "subjects-matters of Common Sense," but also of "Common Sense frame," of "framework of Common Sense," etc. He also talks of "domain." It is this last term that I retain here.

17. "Such (common sense) inquiries are, accordingly, different from those which have knowledge as their goal. The attainment of knowledge of some things is necessarily involved in common sense inquiries, but it occurs for the sake of settlement of some issue of use and enjoyment, and not, as in scientific inquiry, for its own sake," LW 12: 66-7.

18. In the same way, I won't enter here the discussion of knowing if the Reidian reading of Hume is exact. It would be possible to show, that from many angles, the objections made to Hume's scepticism can be nuanced, and that Hume is not that far from the demands of a methodological scepticism founded upon a reading that insists as much on the articulation necessary between the principles of practical life and philosophical knowledge. I'd use as a proof this citation, amongst others, that is found in the First Part of Dialogues Concerning Natural Religion: "That the larger experience we acquire, and the stronger reason we are endowed with, we always render our principles the more general and comprehensive; and that what we call philosophy is nothing but a more regular and methodical operation of the same kind. To philosophize on such subjects is nothing essentially different from reasoning on common life." Hume (2007 [1779], Part I: 10; my emphasis).

19. "The true line of philosophic progress lies, in short, it seems to me, not so much through Kant as round him to the point where now we stand. Philosophy can perfectly well outflank him, and build herself up into adequate fullness by prolonging more directly the older English lines." (James 1975 [1907], Vol. 1, Pragmatism, Appendixes, I "Philosophical Conceptions and Practical Results," 269; my emphasis).

20. Reid (1995; 2015). From now: Inquiry.

21. Inquiry, Introduction: 1. "The Importance of the Subject, and the Means of Prosecuting It," 11-2. My emphasis.

22. "Philosophy" in this text is used in a broad sense in which it also covers science.

23. Inquiry: Ibid.: 12. My emphasis.

24. "But if this impossibility of explaining ultimate principles shou'd be esteem'd a defect in the science of man, I will venture to affirm, tha 'tis a defect common to it with all the sciences, and all the arts, in which we can employ ourselves, whether they be shops of the meanest artizans. None of them can go beyond experience, or establish any principles which are not founded on that authority." Hume, (2007 [1739-40], Vol. 1, § 10: 5-6).

25. Inquiry: Introduction, 3. "The Present State of this Part of Philosophy. Of Des Cartes, Malebranche, and Locke," 16; my emphasis.

26. Inquiry: Ibid.: 16; my emphasis.

27. Still with regard to Descartes, "But why didn't he prove the existence of his thought ('I think, therefore I exist')? You may say 'Consciousness assures him of that.' But who assures him that consciousness is truthful? Can any man prove that his consciousness can't deceive him? No man can; and we can't give a better reason for trusting consciousness than that every man, while his mind is sound, is caused by the constitution of his nature to believe it unquestioningly, and to laugh at or pity anyone who doubts its testimony," Ibid.

28. Inquiry: 17-8; my emphasis.

29. Inquiry: Introduction, V. "Of Bishop Berkeley; the Treatise of Human Nature; and of Scepticism," 21. 
30. Inquiry: 20. Here again, it is not a question of discussing Reid's reading of Hume. A number of considerations close to this can be found. Quite simply because Reid refuses to make a distinction between a excessive scepticism - that which he talks of - and a mitigated scepticism, at least, methodologically contained which can also be understood as a principle of epistemological vigilance. See, on this point, the distinction proposed by Hume (1999 [1748], 12). "Of the Academical or Sceptical Philosophy," 200-2.

31. "That the votaries of this Philosophy, from a natural prejudice in her favour, have endeavoured to extend her jurisdiction beyond its just limits, and to call to her bar the dictates of Common Sense," Inquiry, I. Introduction, 4. "Apology for Those Philosophers," 19; my emphasis.

32. Dewey LW 1, I. "Experience and Philosophic Method," 10-s.

33. LW 1: 28; my emphasis.

34. See Dewey (1905), "The Postulate of Immediate Empiricism," in MW 3: 158-67.

35. LW 1: 29; my emphasis.

36. See Renault (2015: 19-44).

37. LW 1: 30. My emphasis.

38. LW 1: 31. My emphasis.

39. See LW 1: 40; 61; etc.

40. James ([1907] 1975, Lecture VI: 110; my emphasis). De facto, he poses the same question on the distinction between "pragmatism" and "intellectualism."

41. Unity of attitude thus sustained by the exigency of a common method in the three domains, which is of the enquiry: "The attainment of unified method means that the fundamental unity of the structure of inquiry in common sense and science be recognized, their difference being one in the problems with which they are directly concerned, not to their respective logics."(LW 12: 84; my emphasis).

42. LW 16: 245.

43. LW 1: 34.

44. I'm speaking here of "ethology" in the sense where John Stuart Mill in his System of Logic (1843), more precisely in Book IV "The Logic of the Moral Sciences," poses the principle of an ethological science which, as it articulates between the general psychological laws of the human mind on one hand, and on the other historical and empirical regularities, confers to the study of characters the function of linking the psychological level and the empirical level. (See Mill, 1994; see 5. "Of Ethology, or the Science of the Formation of Character," 61-s.) As such it is an analysis of "dispositions." By analogy, I am speaking here of an ethology to designate the common ethos which must link together the attitudes of the scientist, the ordinary man, and the philosopher. Here again the emphasis is placed on the aspects of a certain ethos.

45. LW 1: 30.

46. Emphasised here - without going any further - is the community of preoccupation: the demand for the reconstruction of philosophy in Dewey implied the methodological transposition of the model of the inquiry such as it operated in the universe of the experimental sciences of his time. Just as the search for greater scientific rigour, in Bourdieu, supposed leaving behind the generalist and complacent gestures of a certain fashionable philosophy, and implied, in his eyes, turning towards positive science which could be sociology and/or anthropology.

47. LW 1: 39.

48. LW 1: 41.

49. On philosophy: "Thus, the wisdom of philosophy is set in opposition to the common sense of mankind. The first pretends to demonstrate a priori, that there can be no such thing as a material world; that sun, moon, stars, and earth, vegetable and animal bodies, are, and can be nothing else, but sensations in the mind, or images of those sensations in the memory and imagination; [...] This opposition betwist philosophy and common sense, is apt to have a very unhappy influence upon the philosopher himself. [...] He considers himself, and the rest of his species, as 
born under a necessity of believing ten thousand absurdities and contradictions, and endowed with a pittance of reason, as is just sufficient to make this unhappy discovery [...]." Inquiry, V, 7. "Of the Existence of a Material World," 67-8; original emphasis.

50. Inquiry, I. Introduction, 1 "The Importance of the Subject, and the Means of Prosecuting it,"12-3.

51. LW 16.

52. Which in Reid includes natural philosophy, thus science.

53. Inquiry, V "Touch," 1. "Of Heat and Cold," 55.

54. Inquiry, Chap. VI "Of Seeing," 20. "Of Perception in General," 172.

55. Inquiry, VI, 20: 170.

56. As Hume states in A Treatise of Human Nature (1739-40) when he claims, in the "Introduction": "And as the science of man is the only solid foundation for the other sciences, so the only solid foundation we can give to this science itself must be laid on experience and observation." Hume (2007: 4; my emphasis).

57. As Dewey defines it, specially in his Logic. Theory of Enquiry, LW 12: I-5 "The Needed Reform of Logic," 86-s.

58. LW 16: 250.

59. LW 16: 250-1.

60. I will leave this point partly to one side for reasons of coherence. Reference can be made for an example of presentation to Gail Kennedy (1954: 313-5).

61. Dewey, The Quest for Certainty, LW 4, 1. "Escape from Peril," 20-1.

62. "In the first place, it is a work and a work carried on by a distinct group or set of human beings constituting a profession having a special vocation, exactly as is the case with those engaged in law or medicine," LW 16: 250.

63. LW 16: 250.

64. LW 16: 251.

65. See Dewey (1948b): "Upon the side of theory, of pseudo-philosophy, the attack (against science) rests upon calling the sciences 'materialistic' while literary subjects are identified with whatever is idealistic and 'spiritual' in our traditions and institutions. This position rests back upon belief in the separation of man from nature," in LW 15: 188.

66. LW 16: 250; my emphasis.

67. LW 16: 251.

68. LW 16: 252; original emphasis.

69. This question of the privatisation of the interests of knowledge is a recurrent theme that is found in many texts in Dewey. Its importance can be shown, for example in Dewey (1927-46), The Public and its Problems. See, for example, the developments of chapter IV "Eclipse of the Public," LW 2: 304-s.

70. LW, 16: 255.

71. Kennedy (1954: 314$)$.

72. LW 16: 255-6; original emphasis.

73. LW 16: 253.

74. LW 12: 66 . 


\section{ABSTRACTS}

Throughout his intellectual career, John Dewey was asking the question of relationships between knowledge of common sense and scientific knowledge. We propose to examine these relations in the light of a comparison with Thomas Reid, one of the founding authors of the modern philosophy of common sense. This comparison tries to set up what should be considered as a closer formulation of what knowledge consists in: a matter of attitudes, a set of dispositions. Such a convergent formulation equally means not to bring into conflict or contradiction - in the style of a "dualism" - what are common sense and scientific knowledge. In so doing, it is thus necessary to reshape an operative distinction between those two kinds of "attitudes"; and this distinction is not ontological but decisively methodological, epistemological and, on a practical level, political.

\section{AUTHOR}

\section{CLAUDE GAUTIER}

École Normale Supérieure de Lyon

claude.gautier[at]ens-lyon.fr 